\title{
Involve to improve: A participatory approach for a Decision Support System for coastal climate change impacts assessment. The North Adriatic case
}

\author{
Francesca Santoro $^{\mathrm{a}, 1}$, Marco Tonino $^{\mathrm{a}}$, Silvia Torresan ${ }^{\mathrm{a}, \mathrm{b}}$, Andrea Critto ${ }^{\mathrm{a}, \mathrm{b}}$, Antonio Marcomini ${ }^{\mathrm{a}, \mathrm{b}, *}$ \\ a Department of Environmental Sciences, Informatics and Statistics, University Ca' Foscari Venice, Calle Larga S. Marta 2137, 30123 Venice, Italy \\ ${ }^{\mathrm{b}}$ Centro Euro-Mediterraneo per $i$ Cambiamenti Climatici (CMCC), Impacts on Soil and Coast Division (ISC), Via Augusto Imperatore 16, 73100 Lecce, Italy
}

\section{A R T I C L E I N F O}

Article history:

Available online 29 March 2013

\begin{abstract}
A B S T R A C T
Decision Support Systems (DSS) are considered innovative tools to cope with climate change related issues and support decision-makers in a sustainable management of natural resources and in the implementation of Integrated Coastal Zone Management (ICZM) and adaptation plans. Involving DSS end users since the beginning of the development of a DSS is recognised as fundamental in order to design a tool that can meet stakeholders needs. However, from the analysis of the risk based DSSs at the regional and/or local scale, emerges a lack of application of participatory approaches, despite their acknowledged relevance to the current scientific literature and regulations.

Accordingly, in order to respond to the needs of the DSS end users (i.e. public institutions dealing with coastal management and administration), this paper describes the development of a participative approach for a DSS named DESYCO, aimed at the assessment of climate change related impacts and risks on natural and human systems.

The participative approach was carried out by means of the integration of participative moments in the DESYCO framework, the identification of potential end users through a preliminary stakeholder analysis and finally the design, administration and analysis of a questionnaire addressed to the end users identified in the case study area of the North Adriatic Italian coast.

37 potential DSS end users for the case study were identified and addressed by a survey investigating their knowledge about climate change impacts on coastal zone, ICZM strategy and implementation, DSS functionalities.

The questionnaire allowed to gain information that both confirmed the validity of the methodology choices of DESYCO and supplied some useful contribution to the selection of further stakeholders. From the results it emerges a lack of knowledge about ICZM and climate change issues. Moreover public institutions ask for short time frame hazard scenarios while the DSS, depending on the available information supplied by models, focuses especially on long term scenarios.
\end{abstract}

(c) 2013 Elsevier Ltd. All rights reserved.

\section{Introduction}

Worldwide coastal zones represent irreplaceable and fragile ecosystems with high ecological, economic and social relevance. Coasts are the result of a dynamic and unpredictable interdependent set of subsystems, and they are under increasing anthropogenic pressure being home for the majority of the world population and their economic activities (Nicholls et al., 2009). Climate change

\footnotetext{
* Corresponding author. Calle Larga S. Marta 2137, 30123 Venice, Italy. Tel: +39 041234 8914; fax: +390412348584.

E-mail addresses: fsantoro@unive.it, f.santoro@unesco.org (F. Santoro), marco.tonino@unive.it (M. Tonino), silvia.torresan@cmcc.it (S. Torresan), critto@ unive.it (A. Critto), marcom@unive.it (A. Marcomini).

${ }^{1}$ Present address: IOC/UNESCO, 1 rue Miollis, 75732 Paris, France.
}

and sea level rise represent a serious threat to coastal areas that will increase the risks of erosion, storm surge flooding, changes in water quality and loss of biodiversity (IPCC, 2007; Mee, 2009). The Mediterranean basin has been identified as a climate change "hotspot" expected to undergo environmental impacts considerably greater than in other places around the world (Billé and Rochette, 2008; García-Ruiz José et al., 2011; Giorgi and Lionello, 2008; Lejeusne et al., 2010; Magnan et al., 2009; Perry, 2005; Plan Bleu, 2010).

Consequently, there is a growing demand of management strategies that take into account at the same time the vulnerability of the coastal zones and the needs of the various social and economic coastal sectors (Nicholls and Hoozemans, 1996). These management strategies, like the ecosystem approach, should facilitate decisions despite the high degree of uncertainty related to 
climate change and the complexity of coastal ecosystems (De Santo, 2010).

Integrated Coastal Zone Management (ICZM), born as a strategy aiming to promote sustainability in the development and management of coastal zones, emerged as the most appropriate process for dealing with current and long term problems like climate change threats. Within ICZM, adaptation strategies aim to respond to climate change impacts, and provide the needed scientific information and tools (Sarewicz and Pielke, 2007).

However, while the definition of guidelines and principles of adaptation is done at the higher international level (COM (2007) 354 final; COM (2002) 413; COM (2009) 147 final; UNEP/MAP, 2008), the actual implementation of these strategies occurs at the national and sub-national levels. The main actors involved in the coastal management process are therefore national governments, regional and local authorities and other relevant stakeholders like NGOs and representatives of economic sectors.

In order to develop appropriate adaptation strategies, national and local policy and decision-makers need significant scientific information and useful tools, provided in the most suitable way. However, a disconnect remains at the intersection between climate change science and decision making: the supply of relevant climate information and forecasts at the appropriate spatial and time scale does not currently match the requirements needed on the demand side, particularly for the implementation of adaptation measures (Cutts et al., 2011). This is so also because the issue of uncertainty constrains the ability of scientists to provide definitive answers in situations where management must continue, even in the absence of knowledge (Patwardhan et al., 2009; Stojanovic et al., 2009). For what concerns both the temporal and spatial scales, scientists are not yet able to meet the specific needs of the decision makers about climate change (McNie, 2007); decision makers ask for time horizons of 20-30 years and not long term scenarios (i.e. 100 years) as proposed so far by the scientific community (Tribbia and Moser, 2008). Considering the spatial scale, it has come to light that no method yet exists to provide confident predictions about the impacts of climate change from the regional down to the local scales (Chen et al., 2011). Therefore innovative methods are needed to bridge the gap between the large scale of future climate change scenarios provided by climate models and the fine scale where local impacts happen as a consequence of changed climate conditions.

Among the most innovative tools to be used in coping with climate change in coastal zones, Decision Support Systems (DSSs) are meant to supply the necessary link between the climate change information provided by scientists and the information needed by coastal stakeholders at regional and local levels. For what concerns DSSs for climate change impact analysis, several examples can be found in literature (e.g. Jolma et al., 2010; IGCI, 2001), some of them focussing on coastal zones (e.g. CZMC, 1993; DINAS-COAST, 2006; Engelen et al., 1995; Mokrech et al., 2011; Warrick, 2009; Westmacott, 2001).

Involving DSS end users since the beginning of the development of a DSS is recognised as fundamental in order to design a tool that can meet stakeholders needs (Lautenbach et al., 2009; Matthies et al., 2007; Uran and Janssen, 2003; Westmacott, 2001). However, from the analysis of the risk based DSSs at the regional and/or local scale, emerges a lack of application of participatory approaches, despite their acknowledged relevance to the current scientific literature and regulations. In those few cases where participation is applied, these experiences are related to methods and results of participative approaches applied in DSS development, mostly regarding the identification of DSS stakeholders (Engelen, 2000) and the interface evaluation of the DSS made by the end users (Lawrence et al., 2002).
As far as Italy is concerned, some of the most recent water resource management DSSs (e.g. Soncini-Sessa et al., 2003; Fais et al., 2004; La Jeunesse et al., 2003) focused on the role of stakeholders participation in decision-making and were designed to involve a wide range of actors and stakeholders (e.g. by means of end users analysis and collection of preferences) (Abuzeid and Afifi, 2006). The different steps of a participative approach used in a DSS are outlined by Soncini-Sessa et al. (2003).

In order to respond to coastal stakeholders' needs for useful information and tools for climate change adaptation strategies through a participative process, the Euro-Mediterranean Centre for Climate change (CMCC) developed a participatory approach for a DEcision support SYstem for COastal climate change impact assessment called DESYCO (Torresan et al., 2009, 2010). This DSS, applied to the case study of the Italian North Adriatic coastal area, was developed to assess climate change related impacts and risks on natural and human systems.

The purpose of this paper is therefore to demonstrate the importance of participation and moreover to present the procedure, steps and results of an end-users involvement process for the development of the DSS applied in the case study of the North Adriatic coastal area.

The end users involvement was done by means of the integration of participative steps in the DESYCO framework, the identification of potential DSS end users through a preliminary stakeholder analysis and finally the design, administration and analysis of a questionnaire addressed to the DSS end-users identified in the case study area. The questionnaire was aimed at investigating the knowledge of stakeholders about climate change, DSSs and ICZM.

In the next sections, after a presentation of the case study area, the method and the results of the stakeholder involvement for the development of DESYCO are described and discussed.

\section{Case study description}

The area considered in the case study involves the coastal zone of the two Italian regions of Veneto and Friuli Venezia Giulia, bordering the North Adriatic Sea with an overall length of about $286 \mathrm{~km}$ (Fig. 1). The coastal area covered by the case study runs along the Adriatic Sea from the national border between Italy and Slovenia to the mouth of the southern tributary of the Po Delta system (i.e. Po di Goro).

From a morphological point of view, the sedimentary shores of the area include straight littoral coasts, lagoonal barrier islands, spits, river outlets and salt marshes. On the whole, the Italian Northern Adriatic Sea coast, comprises a very precarious coastal environment subject to continuous morphological changes that can be appreciable even over short geological time scales (Gambolati and Teatini, 2002). Moreover, erosion is still active in many areas both on the coastal sea floor and on the beach since the beginning of the 20th century and especially after 1960 (Bondesan et al. 1995). Many areas, particularly around the Po River Delta, are also located below the mean sea level and affected by natural or induced subsidence (Pirazzoli, 2005). Furthermore, the municipality of Venice has been experiencing an increase in high tide events and consequent flooding of the city (Ferla et al., 2007). Therefore, climate change and sea level rise are poignant issues for the case study area considering both the vulnerability of fragile ecosystems such as coastal lagoons, as well as the concentration of cultural and socio-economic values.

Considering the administrative aspects, the case study area refers to the Friuli Venezia Giulia region, including 3 provinces and 8 coastal municipalities from the Slovenian border to the mouth of the Tagliamento River, and to the Veneto region, including 2 


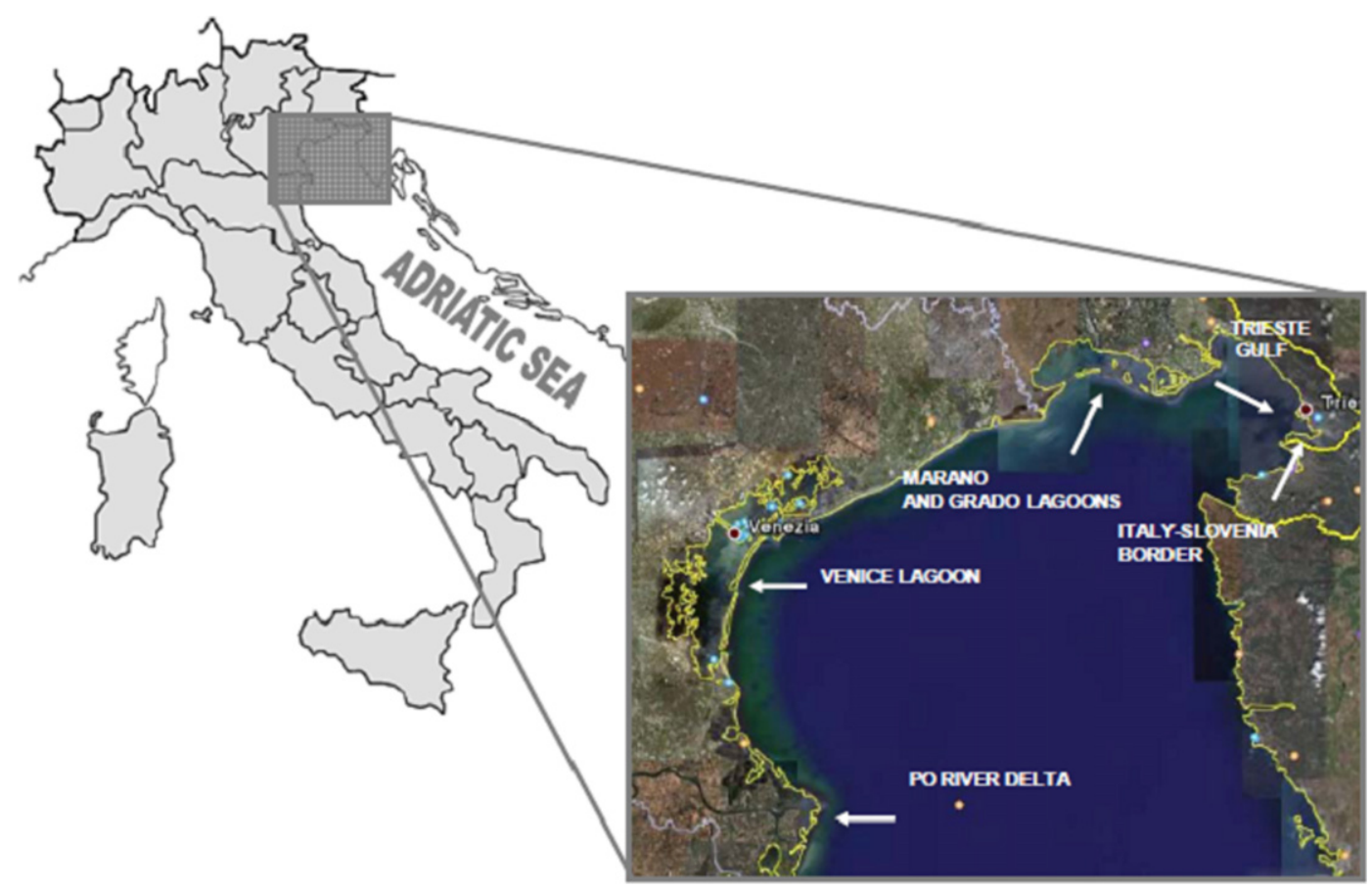

Fig. 1. The case study area: the Northern Adriatic Sea and the coast of the Veneto and Friuli Venezia Giulia regions (Italy). (Adapted from Google maps: maps.google.it).

provinces and 10 municipalities from the mouth of the Tagliamento to that of the Po River.

The Case study is placed in a context, the North Adriatic, of growing economic importance. Several marine and coastal activities, both directly and indirectly linked to the sea, take place in this basin: marine transport, offshore platforms, submarine cables, hydrocarbon survey, fishing, aquaculture, army exercises, scientific research and tourism (Soriani, 2003). The North Adriatic coast also hosts relevant industries and seaport activities. These activities, often conflicting, constitute a threat to the natural resources in the peculiar and delicate context of this basin.

The complexity of the problems linked to climate change and the importance of natural and socioeconomic aspects in the study area call, therefore, for a broad integrated coastal zone management strategy. While at the Italian national level such a strategy is still missing, in the last decade some Italian regions have been developing their own coastal management strategies with notable results. This can be partly explained thanks to the achievement of new competences in the field of the environmental management by Italian regions after the changes of Chapter $\mathrm{V}$ of the Italian Constitution of 2001. Emilia Romagna is the first Italian region to have set up regional guidelines for the integrated management of coastal zone in January 2005 (Rochette, 2009). In 2007, in Sardinia Region, an agency called "Conservatoria delle Coste" was established. This agency is in charge of the safeguard, the recovery and conservation of the Sardinian costal environment and cultural heritage. Since 2004 a special Commission in Lazio (composed by members of the region and the University) was set up to plan, manage and monitor ICZM experimental pilot projects (Lazio Region website).

Considering the case study area, the Veneto and Friuli Venezia Giulia regions have actually not yet developed regional ICZM strategies although in 2007, in Veneto, the "Consulta del Mare" (Sea Committee), a body aimed at the safeguard, protection and repopulation of fishing resources defining actions to be taken over fisheries and marine tourism sectors, was instituted. Among the components of the Committee, there can be found the Region, coastal provinces and municipalities members, port captain's offices, fisheries and aquaculture representatives, marinas and recreational fishing associations. As yet, the Consulta del Mare is inoperative due to the existing conflicts with the fishery sector.

\section{The DSS and its methodological framework}

The DESYCO DSS was developed by the Euro-Mediterranean Centre for Climate Change (CMCC, www.cmcc.it), a national (Italian) research centre devoted to the study of climate change and its impacts. This DSS applies a Regional Risk Assessment (RRA) methodology, an innovative approach not only with respect to the spatial scale of analysis (i.e. the whole coastal area of the Italian North Adriatic Sea), but also for the multi-disciplinary and integrated approach that takes into account downscaled climate change processes (e.g. sea level rise and storm surge flooding, changes in currents and erosion patterns) to characterise climate change hazards at the regional scale; together with biogeophysical and socio-economic factors (e.g. altimetry, geomorphology, land use and vegetation cover) that are also considered in order to determine the vulnerability of the territory posed by climate change impacts and risks (Pasini et al., 2012; Torresan et al., 2010; Torresan et al., 2012).

DESYCO integrates database, scenarios, models, methodologies and decision support tools for the assessment and integrated management of biophysical and socioeconomic impacts linked to climate change in coastal zone at regional to local scale and was integrated in a GIS platform. The ultimate aim of the DSS is to support decision and policy makers in defining the most suitable adaptation strategies in coastal zones.

Generally, the development of a DSS requires three main phases: the definition of a conceptual framework aimed at explaining and justifying the objectives and the main functions of the tool; the definition of the structure where models, databases and their relative functions and interrelations are identified; and finally, the computational realisation of the DSS, including the implementation of the graphical interface for the end user. 
In the DSS construction, three important elements proposed by Salewicz and Nakayama (2004) have to be taken into account in the decision-making process: the considered system, a decision maker and a problem to be solved. In the case of DESYCO, the considered system is represented by a coastal area, the decision-maker is any management authority at the regional scale (e.g. a coastal protection authority) and the problem to resolve corresponds to the assessment and management of the possible impacts and risks linked to climate change. In this context, DESYCO has been considered mainly as a tool that can provide support in the most critical phases of the decision process, namely the integrated impacts and risks assessment phase and the management phase.

The conceptual framework developed for DESYCO integrates tools and methodologies for the identification and assessment of biophysical and socioeconomic impacts of climate change on coastal systems at the regional scale and is composed of three main phases, as shown in Fig. 2. According to Torresan et al. (2010), the first phase of the DESYCO framework is the "Scenarios Construction" phase aimed at the definition of future climate change scenarios for the examined coastal area at the regional scale. The first step of this phase is the selection of impacts to be investigated in the case study (e.g. hydrodynamic impacts, impacts on sea water quality or on soil and groundwater), of the greenhouse gas emission scenario and of the temporal scenario of the analysis (e.g. mid- or long- term scenario). Then it is necessary to select climate change stressors related to each impact (e.g. waves, sea level, temperature, precipitation), to identify factors/metrics associated to each climate change stressor (e.g. wave height, wave energy, water level) and to apply numerical models and/or statistical analysis to define the future spatial and temporal distribution of these factors in relation to different assumptions about socio-economic development, technological change and greenhouse gas emissions. Factors/metrics provided by numerical models are then aggregated and used to construct future climate change hazard scenarios that are input for the Integrated Impact and Risk Assessment phase (Baruffi et al., 2012).

The "Integrated impact and risk assessment" phase is aimed at the prioritization of impacts, targets and areas at risk from climate change at the regional scale. The central core of this phase is the Regional Risk Assessment (RRA) methodology that integrates future climate change hazard scenarios with the biophysical and socioeconomic vulnerability assessment of the system. Specifically, according to Torresan et al. (2012), vulnerability assessment requires the analysis of the site-specific characteristics of a community which increase its sensitivity to the impact of hazards. This step is done through the identification of relevant receptors and vulnerability factors (e.g. physical, social, economic, and environmental factors) for each impact analysed in the case study.

The third and last framework phase is the "Risk and impact management" phase which is devoted to support the definition of adaptation strategies for the reduction of climate change impacts and risks in the coastal zone, according to ICZM principles.

The activities included in the risk and impact management phase are based on results provided by the integrated assessment phase, that are the prioritization of impacts, targets and areas at risk. Such results can be easily and conveniently visualised as maps supporting the decision maker in the identification of priority actions.

\section{The DESYCO participative framework}

Participation can make the DSS more oriented to end users needs by involving them in a process of information exchange. The identification of participative moments should be programmed from the beginning to the end of the DSS implementation in order to make it more suitable to meet the stakeholder and end users information needs.

The participation moments for DESYCO are explicated in the following Box 1 and depicted by means of numbers in yellow circles in Fig. 2 showing their position within the overall DESYCO methodology framework.

Participation moments should take place from the very beginning of the project, during the focus phases of the implementation of the framework and finally at the end of the process to introduce and to evaluate the DSS with all potential end users. At the beginning, a preliminary stakeholder analysis has to be carried out

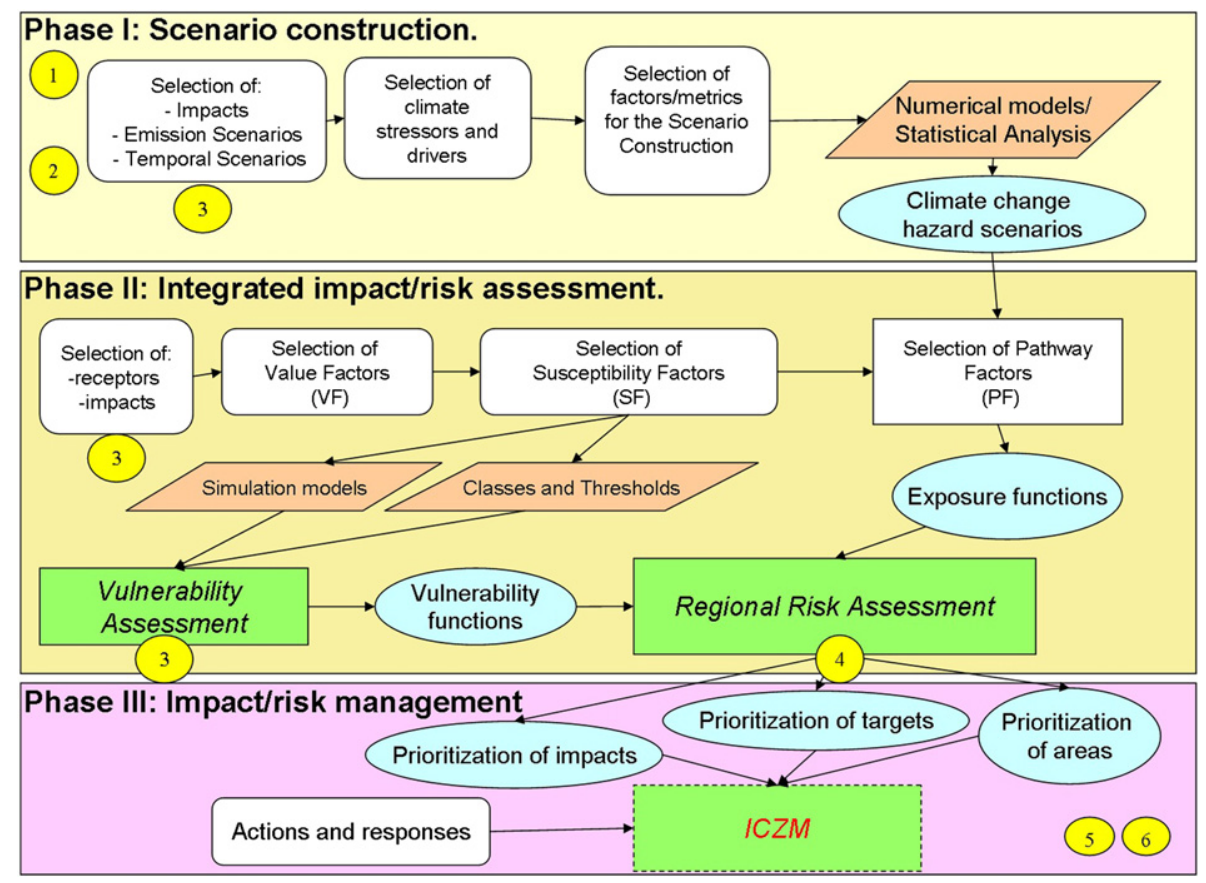

Fig. 2. The phases of the DESYCO framework and the participation moments (numbers in circles from 1 to 6). 
Box 1. Participation phases within the DESYCO Framework project for the assessment and integrated management of impacts and risks linked to climate change in coastal zones

1) DSS end user analysis: In this step, a preliminary stakeholder analysis is carried out in order to define the potential DSS end users for the chosen case study area.

2) Preliminary introduction of the project: All identified end users are invited to take part in a meeting to introduce the DSS project and to check the perceived usefulness of the DSS.

3) Selection of risk parameters: A consultation (questionnaire or workshop) with the end users has to be carried out in order to define and select the following useful information for the DSS development:

- vulnerability factors;

- relevant impacts:

- emission and time frame for scenarios (a trade-off between DSS end user preferences and the available information from models and historical data series has to be reached); and

- coastal zone receptors.

4) Contribution to multicriteria analysis: In the impact and risk assessment phase the end users' opinion can be solicited to help in assigning weights and scores to impacts and receptors.

5) Introduction of the DSS: All identified end users are invited to take part in a meeting to introduce the DSS and to show its functionalities and opportunities for the implementation of adaptation strategies.

6) Monitoring and evaluation: Feedback from end users is solicited in order to eventually modify and improve the DSS.

in order to define who the potential DSS end users are, and a meeting should be organised in order to detect and check the usefulness of the DSS. Furthermore, impacts, emission and temporal scenario selection phases have to be carried out involving end users in order to gain more information and to review the perception of the most critical impacts and more useful time frame for scenarios.

In order to collect the necessary information and to meet end users' needs, a survey should be carried out by means of interviews, questionnaires, forums or workshops according to the number and involvement of end users: a trade-off between DSS end users' needs and the available information has to be reached. Expert opinion is involved, directly or indirectly, in every step of the RRA process (i.e. from hazard characterisation to vulnerability assessment and risk ranking) and is particularly important for the selection of the aggregation functions and in the assignation of weights and scores to risk assessment parameters.

In the impact and risk assessment phase, the involvement of potential DSS end users regards the proposal of impacts and vulnerability indicators and indices. Multicriteria Decision Analysis (MCDA) techniques used in this phase, offer the ability to integrate policy preferences with the judgment of technical experts, thus allowing trade-offs (Giove et al., 2009). These tools could be used to integrate the judgments on the vulnerability assessments of technical experts with the preferences of end users collected by questionnaire.

Once the DSS is ready, it should be presented to all end users, showing its functionalities and opportunities to implement adaptation strategies. Moreover, feedback from end users should be solicited in order to monitor, evaluate and eventually improve the DSS.

\section{Survey for the DESYCO end users}

The contribution of the stakeholders' knowledge should be used in the three main steps of the DESYCO framework: hazard scenario construction, impact and risk assessment, and impact and risk management; at the same time, since the DSS is meant to be used as a tool for climate change adaptation strategies, end users' awareness about climate change threats and integrated coastal management strategy should be checked. Accordingly, there are three main fields that should be investigated by means of participative assessments: the DSS, the climate change, and ICZM. In order to gain the aforementioned information for the DESYCO case study, a survey was aimed at:

- identifying the potential DSS end users for the case study area;

- informing the DSS end users about the project;

- gaining information about the three main fields of climate change, ICZM and DSS in order to improve the DSS according to the end users' needs.

The survey was designed for those public institutions whose management and/or administrative competences regard coastal areas, in particular the ones that could use the DSS directly (i.e. technical institutions and, where applicable, those in charge of town-and-country planning and environmental areas).

In the DESYCO case study, the coastal area considered is part of the two Italian regions of Veneto and Friuli Venezia Giulia; altogether, 37 institutions were identified as addressees for the questionnaire of the case study area as shown in Table 1 . In addition to the already mentioned regions, 5 provinces were selected, namely Trieste, Gorizia, Udine, Venice and Rovigo. Within these provinces, 18 municipalities bordering the sea were considered; furthermore, one river basin authority, 4 port authorities, two civil engineering offices were identified. Finally, two regional offices for environmental protection (ARPA), the upper Adriatic River Basin Authority and the Venice Water Authority, were identified. Due to different competences in coastal management, in provinces and municipalities only town-and-country planning offices were chosen; while in regions the environment department was also taken into account.

\subsection{Development of the questionnaire}

The survey was developed by means of an on-line questionnaire (Annex I) Hulme et al., 2002, Le Blanc, 1991. The questionnaire was chosen due to the possibility to gain information by means of both open and closed format questions; being an on-line questionnaire less time consuming, it can be filled in directly on a webpage without the need to print it or send it back by email.

The questionnaire was developed according to the methodology proposed by Caselli (2005):

a)theme and survey objectives;

b)setting of investigation tools;

c)sampling;

d)questionnaire administration;

e)data collection and data entry in storage devices, data processing and elaboration.

The questionnaire was designed in html language, creating a domain by means of a free web hosting website; it was organised with tick and text boxes in a way that all answers could be directly converted into strings of numbers and words sent automatically to a mailbox. The questionnaire page was structured with an introduction followed by the three main sections corresponding to three main fields of investigation: climate change, ICZM, and the DSS, as 
Table 1

Identified public institutions for the case study area addressed by the questionnaire.

\begin{tabular}{|c|c|c|c|}
\hline Public institution & $\begin{array}{l}\text { Responsibilities in coastal management/ } \\
\text { administration }\end{array}$ & Number & Name \\
\hline Region & Coastal protection Town and country planning & $2(+2)$ & $\begin{array}{l}\text { Friuli Venezia Giulia region: } \\
\text {-Environment protection area } \\
\text {-Town and country planning area } \\
\text { Veneto Region: } \\
\text {-Environment protection area } \\
\text {-Town and country planning area }\end{array}$ \\
\hline Province & Provincial town and country planning & 5 & $\begin{array}{l}\text {-Trieste } \\
\text {-Gorizia } \\
\text {-Udine } \\
\text {-Venice } \\
\text {-Rovigo }\end{array}$ \\
\hline Municipality & Local town and country planning & 18 & $\begin{array}{l}\text { Muggia, Trieste, Duino-Aurisina, Monfalcone, Staranzano, } \\
\text { Grado, Marano Lagunare, Lignano Sabbiadoro, } \\
\text { San Michele al Tagliamento, Caorle, Eraclea, Jesolo, } \\
\text { Cavallino Treporti, Venice, Chioggia, Rosolina, Porto Viro, } \\
\text { Porto Tolle. }\end{array}$ \\
\hline Port Authority & Planning and coordination of ports activities & 4 & $\begin{array}{l}\text {-Trieste } \\
\text {-Monfalcone } \\
\text {-Venice } \\
\text {-Chioggia }\end{array}$ \\
\hline Civil Engineering Office & $\begin{array}{l}\text { Safeguard of water resources, restoration and } \\
\text { maintenance of coastal defences }\end{array}$ & 2 & $\begin{array}{l}\text {-Trieste } \\
\text {-Venice }\end{array}$ \\
\hline $\begin{array}{l}\text { Regional Environment } \\
\text { Protection Agency (ARPA) }\end{array}$ & $\begin{array}{l}\text { Monitoring and safeguard of the state of health } \\
\text { of the sea; integrated management of marine } \\
\text { and coastal habitats, tourism, oceanography }\end{array}$ & 2 & $\begin{array}{l}\text { Arpa FVG: } \\
\text {-Upper Adriatic observatory } \\
\text { Arpa Veneto: } \\
\text {-Upper Adriatic observatory }\end{array}$ \\
\hline River Basin Authority & $\begin{array}{l}\text { Planning of the integrated management of water } \\
\text { resources }\end{array}$ & 1 & -Upper Adriatic River Basin Authority \\
\hline Water Authority & $\begin{array}{l}\text { Venice lagoon reclamation, hydraulic works, } \\
\text { ports and lighthouses }\end{array}$ & 1 & -Venice Water Authority \\
\hline Total & & 37 & \\
\hline
\end{tabular}

shown in the following Table 2. The introduction consisted of a description of the objectives of the questionnaire and of the DSS project about the risks and effects of climate change. The survey mainly aimed at collecting the perceptions of these three issues. In particular, perceptions of the most threatened coastal receptors, relevant impacts and time frame of the impact scenarios are relevant information for the improvement of the DSS framework phases. In the DESYCO, a suite of coastal receptors and climate change impacts were provided. Therefore, an evaluation from the DSS end users was needed to eventually modify or add new receptors and impacts.

The time frame of climate Scenario was another important issue to be investigated; as climate change impacts information are provided by models at a long temporal scale, it was important to check if this kind of scenarios accomplishes the needs of potential end users of the DSS.

Furthermore, considering that the DSS should be used as a tool to implement adaptation actions within a broader coastal zone management strategy, the survey was aimed at investigating the public institutions knowledge level about Integrated Coastal Zone Management.

Before distributing the questionnaire, a text with a description of the aims of the questionnaire and of the DSS project was prepared. This text was then included in the first email sent to the respondents in order to present the DSS project and to explain how to fill in the questionnaire on line. Telephone interviews were conducted for two months. During the first phone call it was decided whether the contact person was apt for the questionnaire, and, if not, contact information for another potential individual or office was solicited. Then, the project was described and permission to send an email with the link to the questionnaire was requested.

The questionnaire data, collected in the form of attached email, were then ordered as text strings in a spreadsheet. Once the survey was over, data for each question was analysed in order to elaborate suitable statistics according to the format of the question. Frequency and mode were the statistics applied to closed format answers, in order to construct bar charts. In order to evaluate open format answers, these were first grouped into macro categories and then statistically analysed to obtain frequency values.

Table 2

Information investigated on climate change, ICZM and DSS by means of the survey directed to the potential end users of the DESYCO-DSS.

\begin{tabular}{|c|c|}
\hline Survey field & Information investigated \\
\hline Climate change & $\begin{array}{l}\text { Perception of: } \\
\text { seriousness of climate change threats; } \\
\text { most relevant climate change impacts; } \\
\text { vulnerability of receptors to climate change; } \\
\text { useful coastal adaption measures; } \\
\text { institutions in charge of managing climate change } \\
\text { adaptation strategies. }\end{array}$ \\
\hline ICZM & $\begin{array}{l}\text { Knowledge about ICZM Perception of: } \\
\text { usefulness of ICZM in coping with climate change } \\
\text { impacts; } \\
\text { suitable institutions to coordinate an ICZM } \\
\text { strategy; } \\
\mathbf{\square} \text { the need for new regulations of coastal } \\
\text { management; } \\
\mathbf{\square} \text { the quality of coastal management measures } \\
\text { taken so far; } \\
\mathbf{\square} \text { the stakeholders to involve in an ICZM strategy; } \\
\mathbf{0} \text { the role taken by the institution represented } \\
\text { by the respondent in an ICZM strategy. }\end{array}$ \\
\hline DSS & 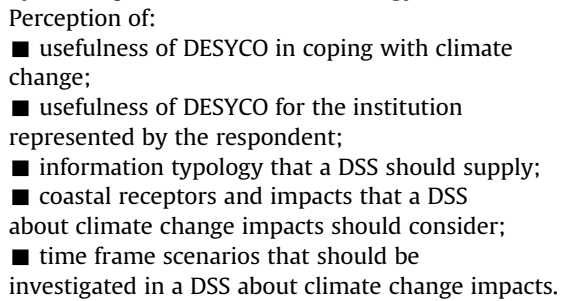 \\
\hline
\end{tabular}




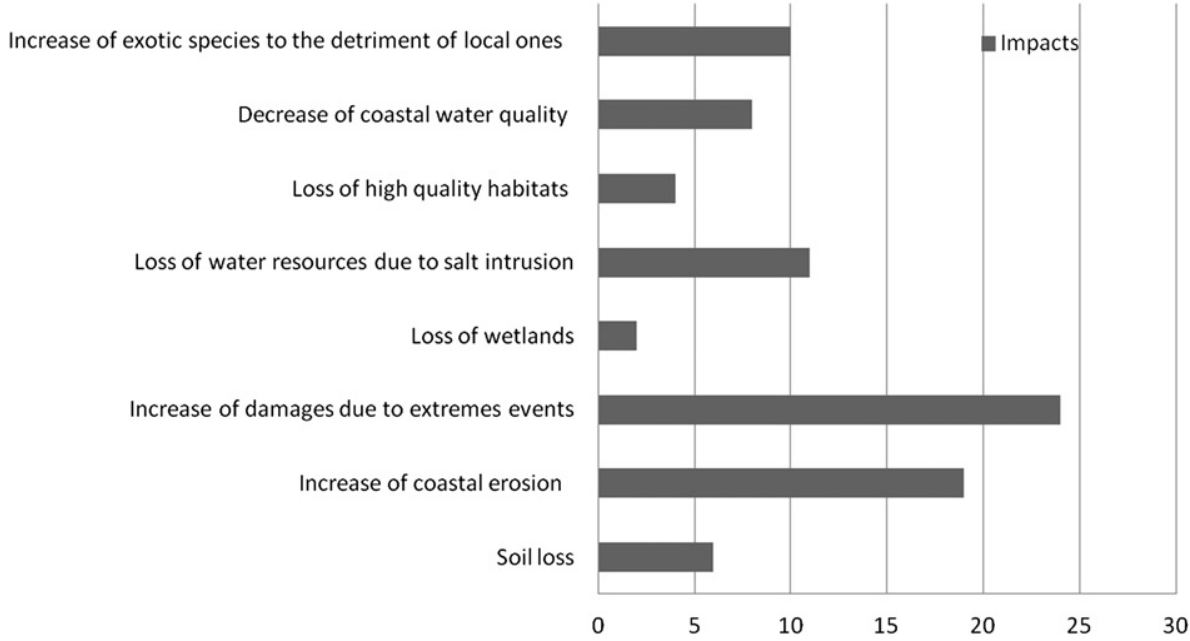

Fig. 3. Number of respondents considering at least as enough important the level of influence of each of the proposed climate change impacts.

\section{Discussion of the results}

Out of the 37 institutions selected for participation, all of them replied to the questionnaire. Therefore, the presented results reflect $100 \%$ of the potential DSS end users identified.

The results of the questionnaire bring to light that, on the whole, the identified potential DSS end users are aware of the ongoing climate change processes regarding the case study of the North Adriatic coastal area. As shown in Fig. 3, coastal institutions are mostly worried about those hydrodynamic impacts due to the increase of coastal erosion and extreme events; however, they are not concerned with two of the main consequences of the rising sea level: the loss of soil and of wetlands. Indeed, the loss of the wetlands should be a concern since several costal wetland areas are expected to disappear due to climate change effects in the 21st century (Nicholls, 2004) especially in the Mediterranean sea (Nicholls et al., 1999).

The receptors ${ }^{2}$ considered more vulnerable by respondents mostly refer to those proposed by the DSS (i.e. beaches and dunes, deltas and estuaries and protected areas). Those considered less vulnerable (namely ports, coastal industrial areas and high coasts) were added on purpose in the questionnaire but are not within the suite of receptors considered by the DSS. However, as it can be seen in Fig. 4, the additional receptor "coastal tourism facilities" is placed in the middle of the ranking of the list of the more vulnerable receptors and, thus, it is advisable to integrate it into the suite of receptors considered in the Regional Risk Assessment procedure.

As shown in Fig. 5 a, on adaptation strategies, public institutions are thinking to implement both urgent actions such as "coastal protection" and long term adaptation actions like an increase in the "no building construction area" that would thus allow a "coastline retreat" process. On the contrary, the latter adaptation choice (i.e. coastline retreat) is not considered useful by the majority of the institutions. Fig. 5 b shows as action for adaptation and mitigation should be taken by the European Union together with national governments and regions according to the respondent. As shown in Fig. $5 \mathrm{c}$, taking prevent action against climate change is perceived as urgent, although Veneto region shows on the whole more concern than Friuli Venezia Giulia.

\footnotetext{
${ }^{2}$ Receptors represent natural or anthropogenic systems of interest due to ecological, economical, or social reasons.
}

As shown in Fig. 6 Integrated Coastal Zone Management (ICZM) is a subject inadequately known among the public institutions of the case study area, even though significant differences exist between the two considered regions. Veneto shows higher knowledge about ICZM than Friuli Venezia Giulia. In fact, while in Veneto further steps in the ICZM path were taken (i.e. setting the Sea Committee for fishery management in 2007), Friuli Venezia Giulia is still deprived of an integrated strategy for coastal management.

The differences among the regions emerged also in consideration of the usefulness of ICZM in coping with climate change, whereas Veneto relies on ICZM more than Friuli V.G.

Less than $50 \%$ of the potential DSS end users gave a definition of ICZM, outlining mainly its sustainability character. In order to improve knowledge of this strategy, DESYCO should supply further information about ICZM (i.e. definition, aims, referring normative) to the end users.

According to the respondents, as shown in Fig. 7, there is no need for brand new bodies to coordinate an ICZM strategy. The majority of them believe that an office with coordinating and/or planning functions is the most suitable choice.

The results of the survey show that there is quite an average need for new plans and policies for coastal zones while $65 \%$ of the respondents highlight the inefficiency of actions taken so far for coastal management.

Addressing the questionnaire to coastal public institutions allowed also for the setting of a preliminary ICZM stakeholder

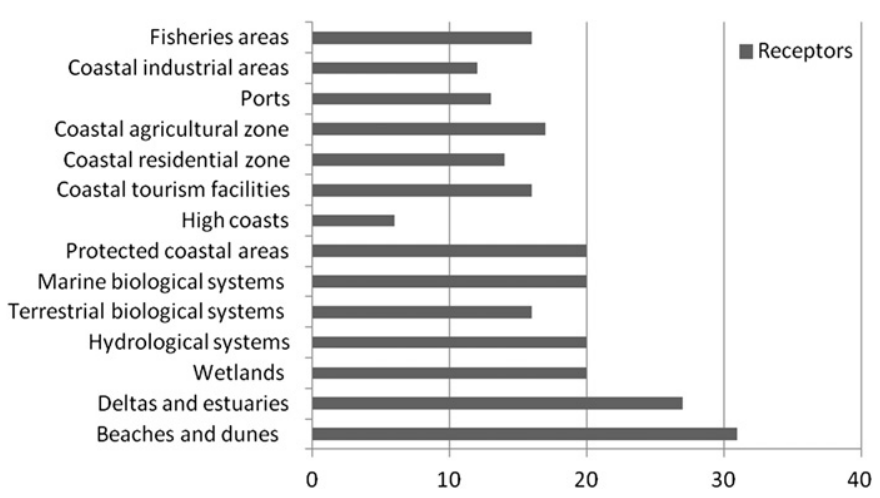

Fig. 4. Bar chart with the number of respondents considering at least enough vulnerable each of the proposed coastal receptor. 


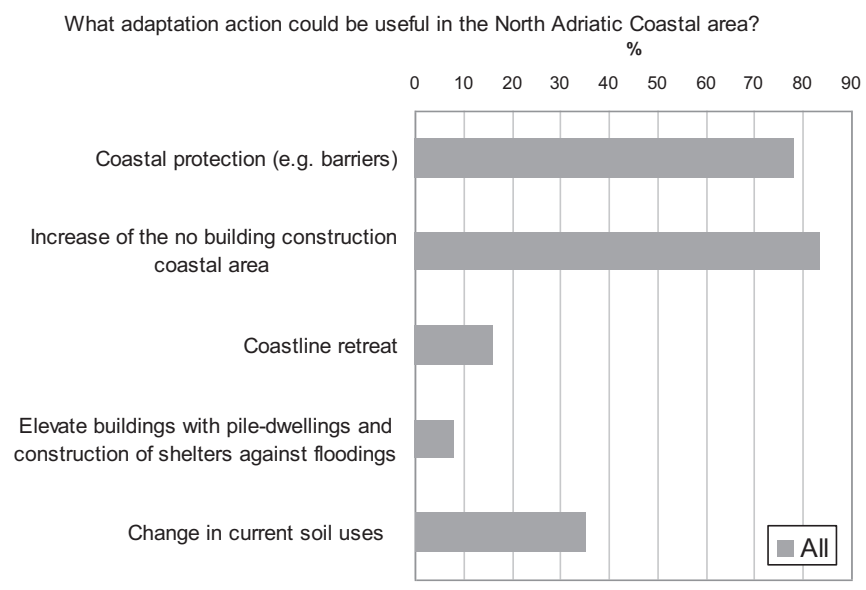

a)

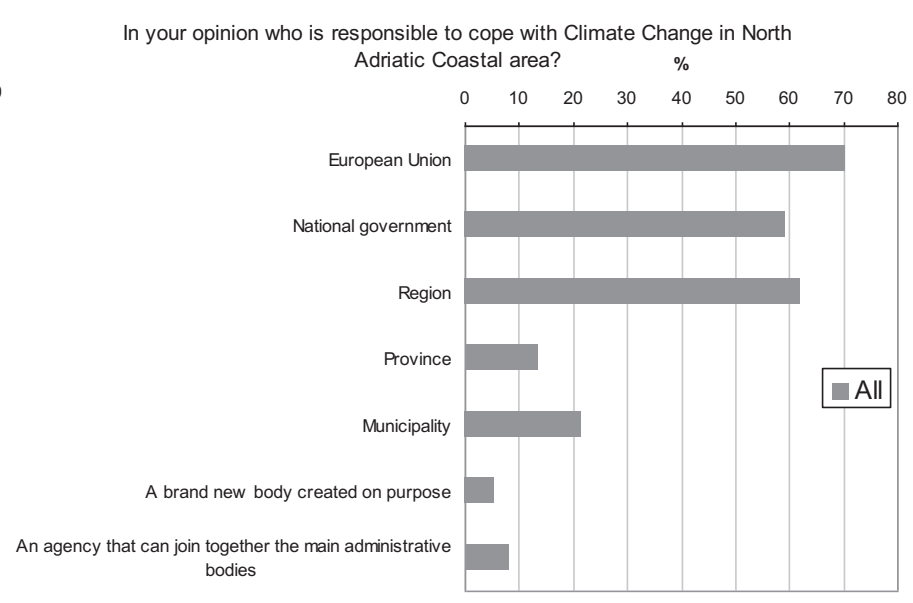

b)

How much urgent is to intervene on climate change on North Adriatic coastal area?

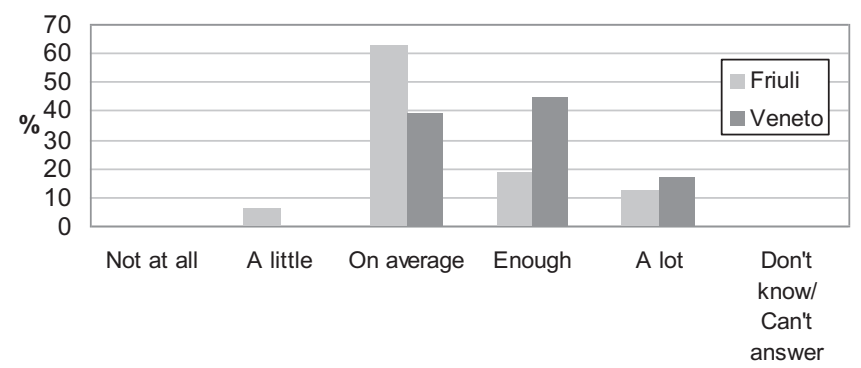

C)

Fig. 5. Bar charts representing a) the perceived usefulness of a set of adaptation actions; b) the institutions responsible to cope with climate change; c) the perceived urgency in intervening on climate change of Friuli and Veneto.

analysis. 34 different categories of stakeholders were mentioned as "useful to involve" in the setting of an ICZM strategy. Within this list, besides the potential DSS end users addressed by the questionnaire, there can be found other public institutions (inter alia universities, park authorities, port captain's offices), NGOs (environmental associations), and economic categories (tourism, fisheries, industry).

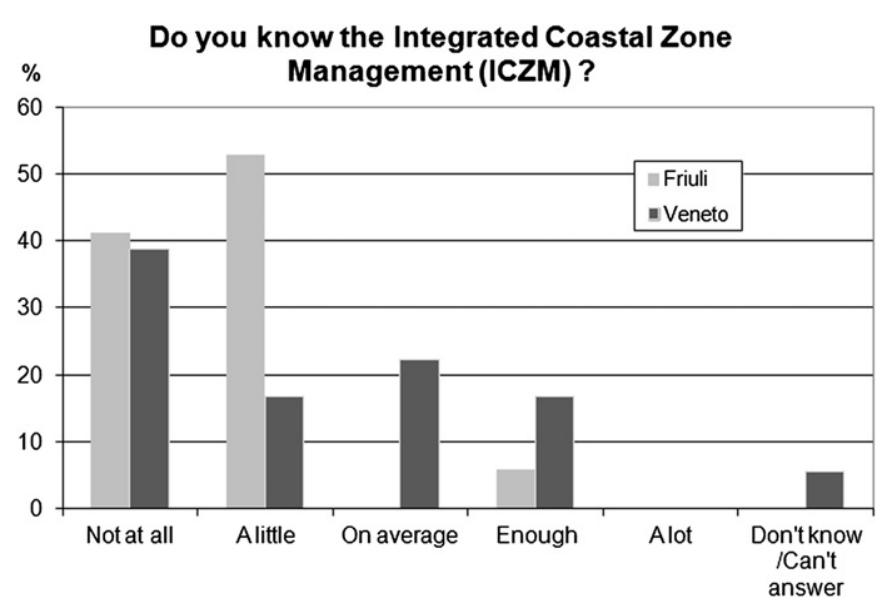

Fig. 6. Bar chart about the ICZM knowledge level of the respondent.
In an ICZM strategy, public institutions recognise that intervention programming, town-and-country planning and the promotion of safeguard policies can be found among the possible roles they should cover.

Questions about the DSS demonstrate that a tool with DESYCO characteristics is generally considered useful due to its several functionalities, mostly for its capability to consider multiple

\section{Which of the following authorities do you think could be the most suitable to coordinate an ICZM strategy?}

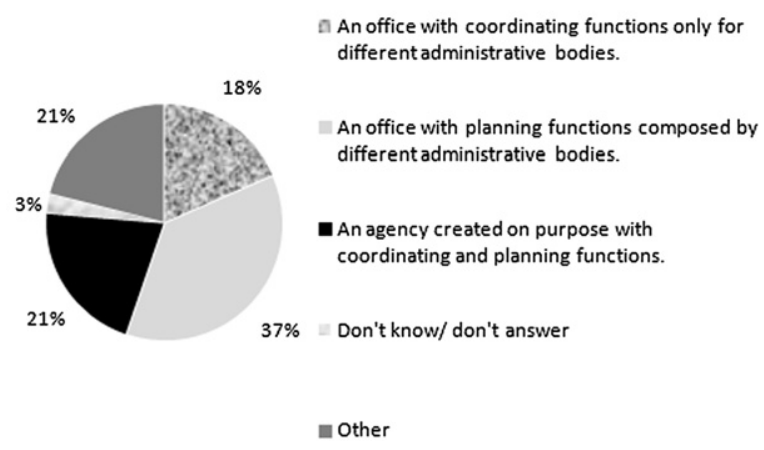

Fig. 7. Pie chart about the suitable authorities to coordinate a ICZM strategy. 


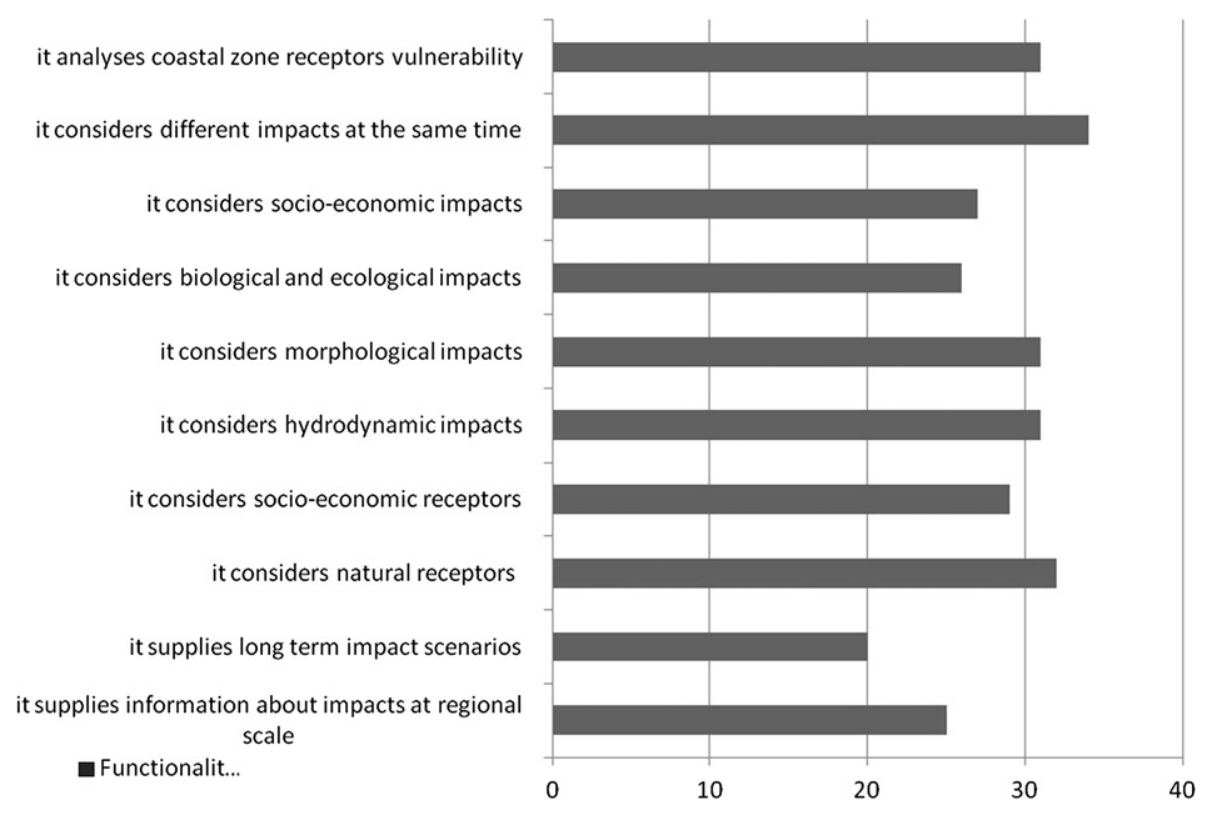

Fig. 8. Bar chart with the number of respondents considering at least enough useful each of the proposed DSS functionalities.

impacts at the same time and for the vulnerability analysis of receptors. As shown in Fig. 8, the DSS is considered helpful for providing information about the effects of climate change on coastal zones while the importance of the DSS in providing highly detailed information is not strongly acknowledged.

As shown in Fig. 9, from the questionnaire emerged that respondents primarily prefer short time frame climate impact scenarios, finding them more useful for the decision-makers in the implementation of short term adaptation strategies.

Those ones asking for long time frame scenarios justified their choice recognising the need to implement long term adaptation strategies. In spite of end user requests, DESYCO, depending on the available information supplied by models, at the moment focuses especially on long term scenarios. Nonetheless, the DSS should provide information to the end users to justify the adoption of these time frame scenarios, underlying the importance of the long term scenarios to implement long term adaptation strategies.

Finally, more than three-quarters of the public institutions surveyed consider that, in the development of a DSS on climate

\section{In your opinion climate change impact scenarios provided by a DSS are more useful at a temporal scale of. \\ respondents}

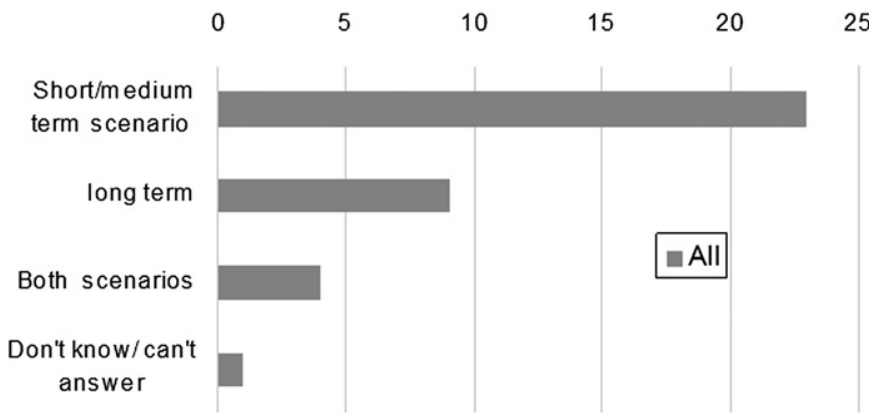

Fig. 9. Bar chart of temporal impact scenarios to be considered in a DSS on climate change impacts according to respondents. change impacts on a regional scale, end users should be involved since the very beginning of the process.

\section{Conclusion}

In this paper, starting from the conceptual framework of the Decision Support System DESYCO, aimed at the integrated assessment and management of climate change impacts and risks on coastal zones on a regional scale, a participative approach for it was developed in order to design a tool according to the needs of end users.

Despite the broad recognition of the importance of end users' involvement in the development of a DSS, only a few studies related to the methods and results of participative approaches applied in DSS development can be found in the existing literature. Therefore this paper is meant to show the steps, methodology and results of the integration of a participatory process in a DSS.

Some of the participation steps of the referring DSS framework were applied by means of a questionnaire in the case study area in order to gain information from the potential DSS end users. This survey allowed for the accomplishment of some of the aims of the participation assessments integrated in the DSS framework; one of the results of the administration of the questionnaire is a preliminary stakeholder analysis for the case study of the Italian North Adriatic coast (from the mouth of the Po River to the Italy-Slovenia border) with the identification of 37 potential DSS end users (i.e. public institutions concerned with the management and/or administration of coastal zones) involved in the questionnaire. In turn, by answering the questions, the respondents suggested further relevant stakeholders' involvement in the development of a DSS. The list of stakeholders identified with the contribution of respondents can be considered a starting point to proceed further in the development of a stakeholder analysis.

Furthermore, the survey allowed for gaining information that both confirmed the validity of the methodology choices and supplied various useful contributions to the DSS framework.

DESYCO should integrate information on ICZM due to the lack of knowledge on this issue emerged from the survey, stressing the role of ICZM in broad strategies that implement action for 
adaptation. Further information on climate change impact severity should be provided to justify methodology choices (e.g. explaining that time frame scenarios are dependent on climate model output).

Future research development on participative approaches in the DSS concerns enhancing the involvement of the end users in the development of the various phases of the DSS framework by means of suitable participation tools and methods (e.g. workshops), thus accomplishing the other proposed participative assessments integrated within the DESYCO framework.

\section{Acknowledgement}

The authors gratefully acknowledge the Euro-Mediterranean Centre for Climate Change (CMCC; Lecce, Italy), CMCC-FISR and GEMINA projects, and the PEGASO FP7 project (Grant agreement no. 244170).

\section{Appendix A. Supplementary data}

Supplementary data related to this article can be found at http:// dx.doi.org/10.1016/j.ocecoaman.2013.03.008.

\section{References}

Abuzeid K., Afifi S., 2006. Multi-sectoral uses of water \& approaches to DSS in water management in the NOSTRUM Partner Countries of the Mediterranean, FEEM Working Paper No. 100.06. Available at: SSRN: http://ssrn.com/abstract=914516 or http://dx.doi.org/10.2139/ssrn.914516.

Baruffi, F., Cisotto, A., Cimolino, A., Ferri, M., Monego, M., Norbiato, D., Cappelletto, M., Bisaglia, M., Pretner, A., Galli, A., Scarinci, A., Marsala, V., Panelli, C., Gualdi, S., Bucchignani, E., Torresan, S., Pasini, S., Critto, A., Marcomini, A., 2012. Climate change impact assessment in Veneto and Friuli plain groundwater. Part I: an integrate modelling approach for hazard scenario construction. Sci. Total Environ. 440, 154-166.

Billé, R., Rochette, J., 2008. ICZM and climate change. Background Document for the International Seminar "The management of coastal zones in the Mediterranean: from local to regional, how to stop the loss of biodiversity?", organised within the EU French Presidency framework, 18-19 December, Nice, France, p.7.

Bondesan, A., Castiglioni, G.B., Elmi, C., Gabbianelli, G., Marocco, R., Pirazzoli, P.A., Tomasin, A., 1995. Coastal areas at risk from storm surges and sea-level rise in north-eastern Italy. J. Coastal Res. 11, 1354-1379.

Caselli, M., 2005. Indagare col questionario: Introduzione alla ricerca sociale di tipo standard. Vita e Pensiero, Milano.

Chen, J., Brisette, F.P., Leconte, R., 2011. Uncertainty of downscaling method in quantifying the impact of climate change on hydrology. J. Hydrol. 401, 190-202.

COM, 2002. 413, Recommendation of the European Parliament and of the Council Concerning the Implementation of Integrated Coastal Zone Management in Europe.

COM, 2007. 354, Final Green Paper, Adapting to Climate Change in Europe - Options for EU Action.

COM, 2009. 147, Final White Paper - Adapting to Climate Change: Towards a European Framework for Action.

Cutts, B.B., White, D.D., Kinzig, A.P., 2011. Participatory geographic information systems for the co-production of science and policy in an emerging boundary organization. Environ. Sci. Policy 14, 977-985.

CZMC, 1993. Coastal Zone Simulation Model (COSMO). Coastal Zone Management Centre, The Hague.

De Santo, M.E., 2010. 'Whose science?' Precaution and power-play in European marine environmental decision-making. Mar Policy 34, 414-420.

DINAS-COAST Consortium, 2006. DIVA 1.5.5. Potsdam Institute for Climate Impact Research, Potsdam, Germany. (CD-ROM).

Engelen, G., 2000. The Wadbos Policy Support System: Information Technology to Bridge Knowledge and Choice. Technical paper prepared for the National Institute for Coastal and Marine Management/RIKZ, The Hague.

Engelen, G., White, R., Uljee, I., Wargnies, S., 1995. Vulnerability Assessment of Lowlying Coastal Areas and Small Islands to Climate Change and Sea-level Rise. Report to the United Nations Environment Programme, Caribbean Regional Coordinating Unit. Research Institute Knowledge Systems (RIKS), Kingston, Jamaica (905000/9379). Maastrict.

Fais A., Dono G., Nino P., Severini S., Bazzoffi P., Napoli R., Giannerini G., Turchi A., Giovacchini A., Minelli U., Perini L., 2005. MONIDRI - A participatory integrated Decision Support System for water use management in agriculture at river basin level. Proceedings of Venice 2004 IFAC Workshop: Modelling and Control for Participatory Planning and Managing Water Systems, Venice, 29 September - 1 October 2004.

Ferla, M., Cordella, M., Michielli, L., Rusconi, A., 2007. Long term variations on sea level and tidal regime in the lagoon of Venice. Estuar Coast Shelf S 75, 214-222.
Gambolati, G., Teatini, P., 2002. GIS simulations of the inundation risk in the coastal lowlands of the Northern Adriatic Sea. Math. Comput. Model. 35, 963-972.

García-Ruiz José, M., López-Moreno Ignacio, J., Vicente-Serrano Sergio, M., LasantaMartínez, Teodoro, Beguería, Santiago, 2011. Mediterranean water resources in a global change scenario. Earth-Sci. Rev. 105, 121-139.

Giorgi, F., Lionello, P., 2008. Climate change projection for the Mediterranean region. Glob. Planet Change 63, 90-104.

Giove, S., Brancia, A., Satterstrom, F.K., Linkov, I., 2009. Decision support systems and environment: role of MCDA. In: Marcomini, A., Suter II, G.W., Critto, A. (Eds.), Decision Support Systems for Risk-based Management of Contaminated Sites. Springer, pp. 53-73.

Hulme, M., Jenkins, G.J., Lu, X., Turnpenny, J.R., Mitchell, T.D., Jones, R.G., Lowe, J., Murphy, J.M., Hassell, D., Boorman, P., McDonald, R., Hill, S., 2002. Climate Change Scenarios for the United Kingdom: The UKCIP02 Scientific Report Tyndall Centre for Climate Change Research, School of Environmental Sciences, University of East Anglia, Norwich, UK, p. 120.

International Global Change Institute (IGCI), 2001. In: Warrick, R.A., Kenny, G.J. Harman, J.J. (Eds.), Effects of Climate Change and Variation in New Zealand- An Assessment Using the CLIMPACTS System. (Hamilton).

IPCC, 2007. Summary for policymakers. In: Solomon, S., Qin, D., Manning, M. Chen, Z., Marquis, M., Averyt, K.B., M.Tignor, Miller, H.L. (Eds.), Climate Change 2007: The Physical Science Basis. Contribution of Working Group I to the Fourth Assessment Report of the Intergovernmental Panel on Climate Change. Cambridge University Press, Cambridge, United Kingdom and New York, NY, USA.

Jolma, A., Kokkonen, T., Koivusalo, H., Laine, H., Tiits, K., 2010. Developing a decision support system for assessing the impact of climate change on lakes. In: George, G. (Ed.), 2010. The Impact of Climate Change on European Lakes, 4. AquatEcol, pp. 411-435.

La Jeunesse, I., Rounsevell, M., Vanclooster, M., 2003. Delivering a decision support system tool to a river contract: a way to implement the participatory approach principle at the catchment scale? Phys. Chem. Earth 28, 547-554.

Lautenbach, S., Berlekamp, J., Graf, N., Seppelt, R., Matthies, M., 2009. Scenario analysis and management options for sustainable river basin management: application of the Elbe DSS. Environ. Modell. Softw. 24, 26-43.

Lawrence, M., Goodwin, P., Fildes, R., 2002. Influence of user participation on DSS use and decision accuracy. Omega 30, 381-392.

Le Blanc, L.A., 1991. An assessment of DSS performance: the impact of utilization and closure. Inf. Manage. 20, 137-148.

Lejeusne, C., Chevaldonne, P., Pergent-Martini, C., Boudouresque, C.F., Pérez, Thierry, 2010. Climate change effects on a miniature ocean: the highly diverse, highly impacted Mediterranean Sea. Trends Ecol. Evol. 25, 250-260.

Magnan, A., Garnaud, B., Billé, R., Gemenne, F., Hallegatte, S., 2009. The Future of the Mediterranean: From Impacts of Climate Change to Adaptation Issues. IDDRI p. 42. http://www.iddri.org/Publications/Rapports-and-briefing-papers/IDDRI_ MEEDDAT_The_Future_of_the_Mediterranean_EN.pdf.

Matthies, M., Giupponi, C., Ostendorf, B., 2007. Environmental decision support systems: current issues, methods and tools. Environ. Modell. Softw. 22, 123-127.

McNie, E.C., 2007. Reconciling the supply of scientific information with user demands: an analysis of the problem and review of the literature. Enviro Sci. Policy 10, 17-38.

Mee, L., 2009. Between the Devil and the Deep Blue Sea: the coastal zone in an Era of globalisation. Estuar Coast Shelf S 96, 1-8.

Mokrech, M., Hanson, S., Nicholls, R.J., Wolf, J., Walkden, M., Fontaine, C.M., Nicholson-Cole, S., Jude, S.R., Leake, J., Stansby, P., Watkinson, A.R., Rounsevell, M.D.A., Lowe, J.A., Hall, J.W., 2011. The Tyndall coastal simulator. J. Coast. Conserv. 15, 325-335.

Nicholls, R.J., 2004. Coastal flooding and wetland loss in the 21st century: changes under the SRES climate and socio-economic scenarios. Glob. Environ. Chang. 14, 69-86.

Nicholls, R.J., Hoozemans, F.M.J., 1996. The Mediterranean: vulnerability to coastal implications of climate change. Ocean Coast Manage. 31, 105-132.

Nicholls, R.J., Hoozemans, F.M.J., Marchand, M., 1999. Increasing flood risk and wetland losses due to global sea-level rise: regional and global analyses. Glob. Environ. Chang. 9, S69-S87.

Nicholls, R.J., Mokrech, M., Hanson, S., 2009. An integrated coastal simulator for assessing the impacts of climate change. IOP C Ser. Earth Environ. 6.

Pasini, S., Torresan, S., Rizzi, J., Zabeo, A., Critto, A., Marcomini, A., 2012. Climate change impact assessment in Veneto and Friuli Plain groundwater. Part II: a spatially resolved regional risk assessment. Sci. Total Environ. 440, 219-235.

Patwardhan, A., Downing, T., Leary, N., Wilbanks, T., 2009. Towards an integrated agenda for adaptation research: theory, practice and policy: strategic paper. Curr. Opin. Environ. Sustainability 1, 219-225.

Perry, A., 2005. The Mediterranean: how can the World's most popular and successful tourist destination adapt to a changing climate? In: Hall, C.M., Higham, J. (Eds.), Tourism, Recreation and Climate Change, pp. 86-96.

Pirazzoli, P.A., 2005. A review of possible eustatic, isostatic and tectonic contributions in eight late-Holocene relative sea-level histories from the Mediterranean area. Quaternary Sci. Rev. 24, 1989-2001.

Plan Bleu, 2010. Evaluation of the Economic Impacts of Extreme Event in Mediterranean Countries. Valbonne, (Blue Plan Papers 5).

Rochette, J., 2009. Challenge, dialogue, action... Recent developments in the protection of coastal zones in Italy. J. Coast Conserv. 13, 131-139.

Salewicz, K.A., Nakayama, M., 2004. Development of a web-based decision support system (DSS) for managing large international rivers. Glob. Environ. Chang. 1, 25-37. 
Sarewitz, D., Pielke, R.A., 2007. The neglected heart of science policy: reconciling supply of and demand for science. Environ. Sci. Policy 10, 5-16.

Soncini-Sessa, R., Castelletti, A., Weber, E., 2003. A DSS for planning and managing water reservoir systems. Environ. Modell. Softw. 18, 395-404.

Soriani, S., 2003. L'articolazione Spaziale Dello Spazio Costiero. Il Caso Dell'Alto Adriatico, p. 228. Cafoscarina, Venice.

Stojanovic, T.A., Ball, I., Ballinger, R.C., Lymbery, G., Dodds, W., 2009. The role of research networks for science-policy collaboration in coastal areas. Mar Policy 33, 901-911.

Torresan S., Critto A., Tonino M., Alberighi E., Pizzol L., Santoro F. and Marcomini A., 2009, Climate change risk assessment for coastal management, In: Özhan, E. (Ed.), In: Proceedings of the Ninth International Conference on the Mediterranean Coastal Environment, 10-14 November 2009, Sochi, Russia, MEDCOAST, Middle East Technical University, Ankara, Turkey, pp. 91-102.

Torresan S., Zabeo A., Rizzi J., Critto A., Pizzol L., Giove S., Marcomini A., 2010. Risk Assessment and Decision Support Tools for the Integrated Evaluation of Climate Change Impacts on Coastal Zones, International environmental Modelling and Software Society (IEMSs), International Congress on Environmental Modelling and Software Modelling for Environment's Sake, Fifth Biennial Meeting, Ottawa,
Canada David A. Swayne, Wanhong Yang, A. A. Voinov, A. Rizzoli, T. Filatova (Eds.) http://www.iemss.org/iemss2010/index.php?n=Main.Proceedings.

Torresan, S., Critto, A., Rizzi, J., Marcomini, A., 2012. Assessment of coastal vulnerability to climate change hazards at the regional scale: the case study of the North Adriatic sea. Nat. Hazard. Earth Sys. 12, 2347-2368.

Tribbia, J., Moser, S.C., 2008. More than information: what California's coastal managers need to plan for climate change. Environ. Sci. Policy 11, 315-328.

UNEP/MAP, 2008. Protocol on Integrated Coastal Zone Management in the Mediterranean (Athens).

Uran, O., Janssen, R., 2003. Why are spatial decision support systems not used? Some experiences from the Netherlands. Comput. Environ. Urban 27, 511-526.

Warrick, R. A., 2009. Using SimCLIM for modelling the impacts of climate extremes in a changing climate: a preliminary case study of household water harvesting in Southeast Queensland. 18th World IMACS/MODSIM Congress, Cairns, Australia 13-17 July 2009.

Westmacott, S., 2001. Developing decision support systems for integrated coasta management in the tropics: is the ICM decision-making environment too complex for the development of a useable and useful DSS? J. Environ. Manage. $62,55-74$ 